\title{
NEW FAMILY CODE AND THE DEJUDICIALIZATION OF DIVORCE IN SLOVENIA
}

\author{
Suzana KRALJÍ́ \\ E-mail: suzana.kraljic@um.si \\ Associate professor \\ University of Maribor, Faculty of Law, Slovenia
}

\begin{abstract}
In April 2019, the new Family Code came into force in Slovenia, replacing the Marriage and Family Relations Act from 1976. The latter was revised three times, but the family law required and especially children's law radical substantive, both material and procedural changes and adjustments. One of the key novelties of the new Family Code is the extension of the powers of Slovenian notaries. In addition to their pre-existing responsibilities (e.g. agreement on the division of joint property), the new Family Code also gave them jurisdiction in the area of divorce. The spouses may, by fulfilling prescribed legal requirements, divorce by mutual agreement before a notary. The spouses are, therefore, allowed to reach an uncontested divorce without the involvement of the court, as has been done transiently by many European and non-European countries. The Slovenian legislature wanted to simplify, facilitate and shorten the divorce procedure on one hand, and on the other hand, this new regulation would also contribute to the relief of the courts and the increase of the spouses' autonomy. The author analyses the new legal arrangement for an uncontested divorce before a notary in Slovenia and in the selected comparative national regulations.
\end{abstract}

Key word: uncontested divorce, autonomy, notary, agreement, notarial deed 


\section{Introduction}

Slovenia, in past years, went through turbulent times in the field of family law. As one of the former Yugoslav republics, Slovenia has, after almost a decade of negotiations and co-operations (Kraljić \& Rijavec, 2018, p. 1), and two legislative referendums (Kraljić, 2017, p. 63), on 21 March 2017, finally adopted the new Family Code (Družinski zakonik - FC). The FC has been in force since 15 April 2019. In addition, on 21 April 2016, Slovenia adopted the new legislation on civil unions. Currently, partners from same-sex civil unions have all, but three, of the rights and obligations that come with marriage: they cannot enter into marriage, jointly adopt a child or use the system of in-vitro fertilisation (art. 2(3) and 3(4) Civil Union Act (Zakon o partnerski zvezi - CUA) (Kraljić, 2017, p. 66-70).

The FC also introduced changes which increased the competences of Slovenian notaries. The goals pursued by the legislature were, in particular, to ensure the legal certainty of participants in family relations and to facilitate the regulation of them in accordance with their wishes and needs (e.g. permitting the possibility for spouses to conclude contracts regulating matters pertaining to property). Another goal was to reduce burdens and caseloads of the courts such as by, for example, the simplification, expedition and facilitation of certain procedures (e.g. the possibility of a divorce by a notary). In addition to novel procedures relating to the enhanced jurisdiction of notaries, the FC has also established many other welcome improvements, including substantial changes or the elimination (marriage by proxy) of certain family law institutes. Finally, the FC has also made terminological adjustments to current family law guidelines. Thus, e.g. the former term 'parental right' was replaced by the term 'parental care', a modification that attests to the child-centered orientation of the new FC.

The FC is also complemented by the new Non-Contentious Civil Procedure Act (Zakon o nepravdnem postopku - NCCPA-1), which entered into force simultaneously with the FC. The NCCPA-1 is an important procedural legal Act, as the FC has transferred jurisdiction either from social work centers (adoption, guardianship, foster-care) or from litigation to non-contentious courts (matrimonial matters).

Since Slovenia became an independent state in 1991, its crude marriage rates (CMRs) have declined. According to the Statistical Office of the Republic of Slovenia (n.d., I), in 1992 CMRs were 4.6 marriages per 1000 people, while in 2005 they reached their lowest level, at 2.9 marriages per 1000 people. According to the latest data recorded in 2018, the most marriages were recorded after that year (ie., 2018), with CMRs of 3.5 marriages per 1000 people. The OECD thus ranks Slovenia among the countries (also Chile, Italy, Luxembourg and Portugal) with very low CMRs. In contrast, in other countries, such as Lithuania and Turkey, the CMRs are twice as high at 
around 7 marriages per 1000 people or above (OECD, 2019). On the other hand, the crude divorce rate (CDR) in the last 20 years has been quite stable in Slovenia. CDR in Slovenia was the lowest in 1995, when there were only 0,8 divorces per 1000 people. The divorce rate was the highest in the years 2005 and 2007 with 1,3 divorces per 1000 people (SURS, n.d.). Based solely on CDRs, Slovenia belongs, among the OECD countries, grouped in with the countries with the lowest CDR (OECD, 2019). However, it should be noted that Slovenia is one of the countries with a very high percentage of extramarital unions. Although it is not possible to give an exact number of extramarital unions in Slovenia, since no formalities are required for its formation (art. 4(1) FC: "Extra-marital union is a long -lived union of man and woman who have not been married, and there are no reasons which would result in a marriage being invalid. Such a union has the same legal consequences under this Code as if they had been married; ..."), however, extra-marital unions are the fastest growing family type in Slovenia. Their number has increased by 5,500 in the last three years (SURS, 2018). One of the key indicators that extra-marital unions are widespread in Slovenia is the relatively high birth rate of children born out of wedlock. Slovenia ranks in the top three among the EU countries in terms of children born out of wedlock. In 2016, France had the highest number of children born out of wedlock $(59.7 \%)$, followed by Slovenia and Bulgaria (both 58.6\%). The fewest were born in Greece (9.4\%) and Croatia (18.9\%) (Eurostat, 2018).

The FC thus established procedures aimed at ensuring, on the one hand, the legal certainty of participants in family relationships, primarily of course children, and, on the other hand, facilitating procedures and enabling participants to arrange family relationships in accordance with their wishes and needs. The latter is reflected through the extension of the autonomy of participants in these relationships. The key novelties established by the FC are, for example, the possibility of marriage without witnesses (art. 36(2) FC), the conclusion of a contract for the regulation of property relations (art. 85 FC), the forming of an anticipated will (art. 144 FC), and the transfer of jurisdiction from social work centers to non-contentious courts, etc.

One of the other major novelties is the possibility of a divorce by mutual consent without the involvement of the court. Divorce can also be brought before a notary (art. 97 FC). By introducing these options, Slovenia joined the countries that had already legalized different options for divorce without the court's involvement, such as divorce before a notary (Spain, France) or a civil registry office (Portugal). Such delegations of jurisdiction changed existing divorce procedures (Gromova \& Ivanc, 2020, p. 12) and make it possible to take the recent tendency to shift the handling of certain matters from the judicial systems into account, thereby relieving burdens of the judicial authorities (comp. C-484/15 and C-372/16). The term dejudicialization' 
(German Entjustizialisierung; French déjudiciarisation) is used to characterize this kind of transfer of or ceding of jurisdiction.

\section{Comparative overview of the dejudicialization of divorce}

With the aim of facilitating, accelerating and simplifying a divorce and relieving the courts, some countries have legalized the possibility of divorce without court involvement.

In France, the most recent legislation regulating divorce and the introduction of the possibility of divorce without the participation of a judge was carried out on 18 November 2016 by a Reform Law (Loi $n^{\circ}$ 2016-1547) (Ferrand, 2017, p. 146). Since 1 January 2017, it now is possible in France to divorce without court involvement. If the spouses want to get divorced before a notary, they must agree and conclude a divorce agreement, in which they resolve the typical issues that often arise in divorce cases (e.g. residence of the children and their alimony, compensatory allowance, division of property and debts) (Notaires de France, n.d). The spouses then have 15 days to (re)consider (cooling-off period) and can withdraw from the agreement during that time. This divorce agreement must be countersigned by the attorneys representing the respective parties (the presence of two attorneys is mandatory). Point by point, the agreement must record all the legal effects of divorce and must also include an appendix which contains a statement of assets. After the expiry of the fifteen-day period, one of the attorneys then passes the agreement to a notary who determines whether all formal procedural requirements, both in terms of form and time, are fulfilled. If modifications or changes are required, the notary advises the attorneys who in conjunction with their clients make the necessary changes before then passing the revised agreement back to the notary for final approval. The divorce agreement is therefore a private agreement between the spouses. The notary only exercises formal, but not substantive control, over such private agreements and gives the agreement a definite date which triggers its enforceability. The notary then enters the divorce agreement into the register, which also becomes an enforceable title (Eskenazi et al., 2017; Ferrand, 2017, p. 178).

Spain adopted important reforms of marriage and divorce in 2005 (the marriage was opened also for same-sex couples) and 2015. In 2015, Spain adopted the Law on Non-Contentious Proceedings (Ley 15/2015, de 2 de julio, de la Jurisdicción Voluntaria - Ley 15/2015), which makes it possible for notaries to grant uncontested divorces (and also by secretaries of the court) (Ribot, 2018, p. 185; Ferrer Riba, 2017, p. 123). A divorce proceeding before a notary has the benefits of being faster and cheaper for the parties than the traditional proceeding before a court. It shortens the divorce process from 
approximately half a year to approximately a month (Perez de Vargas, 2020). In Spain, spouses can be divorced before a notary by signing a document containing a declaration of their wish to divorce. Divorce before a notary requires not only that the divorce be consensual but also that the spouses have no minor children or disabled descendants, regardless of age (art. 54 Ley 15/2015). However, if the spouses have adult children who are still economically dependent on them, the child or children must approve those parts of the agreement on matters relating to them (e.g. maintenance, residence) (Ferrer Riba, 2017, p. 137). Their consent is crucial because otherwise the agreement will not be approved and, as a result, the divorce will not be allowed. Both spouses must be physically present at the same time (Crespo \& Marbella, 2016). Although this is a mutual agreement before a notary, the participation of an attorney on behalf of the divorcing spouses is obligatory (whereas there is no requirement for the child or children to have counsel), as the attorney can give them adequate legal assistance before signing the notary deed. An attorney must also sign a notarial deed confirming not only his presence in the divorce proceedings but also the legal counselling provided (Marbella Solicitors, 2018). The notary must be officed in the municipality in which the spouses had their last marital residence, or in which one of the spouses has his current residence. In Spain, there were 101.294 divorces in 2016: 67,944 were resolved by judicial decision $(67,1 \%), 26,998$ by mutual agreement before the court clerk $(26,6 \%)$ and 6,352 by mutual agreement before a notary $(6,3 \%)$. The average duration of the proceedings in court was 4.7 months while the duration of notarial divorce was only one week (Alvaro Lucini, n.d.).

In Estonia, either a Vital Statistics Office (perekonnaseisuametnik) or a notary may grant a divorce by a joint written agreement between the spouses on the basis of a joint written petition and on the further condition that both spouses reside in Estonia. In a personally drawn up agreement, the spouses must confirm that there is no dispute regarding the children, division of joint property or maintenance (art. 64 Family Law Act; European Judicial Network, 2020;Kabátek, 2019). A divorce will not be granted earlier than one month no later than three months from the date of submission of a petition. If the divorce is at the Vital Statistics Office, the state fee must be paid before submitting the application. If the divorce is at the notary, the notary fee (64 Euros plus value added tax) has to be paid upon divorce. This fee covers acceptance of the petition for divorce, the counselling prescribed by the Notary Fees Act and preparation of an entry to the population registry (art. 33(1) Notary Fees Act).

In 2017, by the Law 4509/2017, Greece amended the legal regulation of divorce. The amendment legalizes the possibility of divorce before a notary. Article22 of this amendment authorizes the dissolution of a marriage before a notary within 12 days (Charakopoulou, 2019). Updated art. 1438, in 


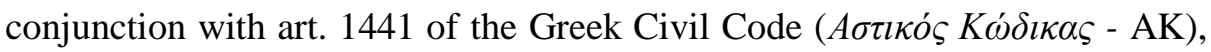
therefore provides for the possibility of divorce on the basis of a private agreement between the spouses. The spouses must include an attorney who also signs the divorce agreement with them (art. 1441(1) AK). Spouses may also divorce before a notary even if they have minor children, so long as they reach agreement about parental responsibility, contact regulation and child maintenance. One limitation and potential drawback is that the agreement is only valid for two years (art. 1441(2) AK). Therefore, the spouses are obliged to renegotiate the agreement, related to children, after two years and to adapt the agreement to any new circumstances. The divorce agreement and the agreement about the children, if they have any, must be signed by either the spouses and their attorneys, or only by the attorneys, if the power of attorney was given at least one month before the signature of agreement (Charakopoulou, 2019). At least ten days have to pass after the divorce agreement is signed before the spouses (including the attorneys) may sign the notarial deed on the divorce (art 1441(3) AK; Androulidakis-Dimitriadis \& Poulou, 2019). The rationale behind the waiting period is for the couple to reflect and reconsider their decision (Charakopoulou, 2019). The marriage is not considered terminated and the divorce finalize, and having the erga omnes effect until the notarial deed on the divorce is entered at the Registry Office, where the marriage was registered, (art. 1441(5) AK; also Economou, GC \& Associates, 2018).

In 2010, Romania also legalized the possibility of divorce before a notary with the New Civil Code (Noul Codul civil al României - NCCR). Articles 375-378 NCCR, as well as the Law on Public Notaries and Notary Activity, provide the legal basis for divorce before a notary. Art. 375(1) NCCR provides that if the spouses agree to the divorce and do not have minor children, the notary in the place where the marriage was entered into, or where the last joint domicile of the spouses was registered, may declare the marriage to be dissolved through the agreement of the spouses. The notary will issue a divorce certificate (European Judicial Network, 2015). Therefore, in order for the spouses to be able to divorce by mutual agreement, two prerequisites must be fulfilled: the spouses must conclude a divorce agreement and must not have minor children (Crăciun, 2014). Divorce through the agreement of the spouses may be declared by a notary also, even if there are minor children, so long as the spouses agree on all the aspects relating to names, exercise of parental authority, establishment of the domicile of the children, ways of maintaining personal relationships, and the establishment of the parents' contribution to the expenses related to the children's upbringing, education, schooling and vocational training (art. 375(2) NCCR; European Judicial Network, 2015; Floare, 2018, p. 151). 
In Brazil, since $2007^{1}$ spouses have had the option of being divorced before a notary. As is true in other countries utilizing this option, non-judicial divorce is more advantageous because it is faster, cheaper and less distressful for the spouses than the traditional court divorce proceeding. Current art. 733 of the Brazilian Código de Processo Civil allows non-judicial divorce if there are no unborn or incompetent children and certain other legal requirements are observed. Non-judicial divorce may be realized by means of a public deed, which shall contain the provisions dealt with in art. 731. The notary shall only draft the public deed if the spouses are assisted by their attorneys or by a public defender whose identification and signature must be contained in the notarial act (art. 733 BCPC).

Act No. 155 of 9 August 2016 amended Codigo Civil de Puerto Rico. It authorizes notaries in Puerto Rico to perform divorce proceedings without the need of a court action under certain conditions. In cases where the spouses have minor or disabled children, where they have joint property or joint debts to liquidate and/or divide amongst them, then divorce before a notary is not permissible. In other case where divorce is possible before a notary, notaries may perform divorces by means of a public deed. The divorce can be granted so long as there is a showing of an irreparable rupture in the marriage. The proceeding before a Puerto Rico notary requires the consent and presence of both spouses. Their consent will be formalized by means of a public deed in which they will express their intention of dissolving their marriage. Assuming they do not revoke their consent, the divorce becomes final 30 days after both spouses sign the public deed (Pellot Gonzalez, 2018).

Since 1995, Portugal law also has provided for the possibility of extrajudicial divorce. Decree Law No. $131 / 95$ made it possible for mutually consenting spouses to request, at the Civil Registry, both a divorce and a judicial separation, in situations where either the couple has no minor children or, if they do, when custody has been judicially resolved (de Oliveira, 2002, p. 2). In 2001, the Decree Law No. 272/2001 on the dejudiziation of divorce by mutual consent, gave exclusive competence for separation and divorce on the ground of mutual consent to the Civil Registry Office (de Oliveira, 2002, p. 3 ). The divorce may be requested in the Civil Registry Office, in person or online. It is possible to lodge an electronic divorce request for no-fault collaborative divorce at the Civil Registry Office. In both cases, divorce is simpler and faster and in specific cases, such as where there are no children, real property, maintenance, or common address, the divorce decree can be made within one hour. Divorce by mutual consent must be accompanied by a detailed agreement relating to the couple's communal property, the disposal of the marital home (if any), the payment of maintenance to the spouse in

\footnotetext{
${ }^{1}$ In Colombia, the government implemented regulations on mutual consent divorce in front of a notary already in year 2005 with the Decree 4436 of November 2005 (UNCHR, 2020).
} 
need of maintenance (if any) and a certificate of the court judgment regulating the exercise of parental responsibility or agreement on the exercise of parental responsibility with regard to any minor children, where this has not been previously ruled on by the courts (European Judicial Network, 2019b; de Oliveira \& Vitor, 2019).

\section{The Divorce Facilitation}

On the one hand, Slovenia has a low level of CMRs, while on the other hand it experiences a high prevalence of extra-marital unions. Despite the fact that the previous regulation already was based on a liberal approach to divorce, Slovenia liberalized divorce even further with the new regulation. Today, divorce, as a way of ending marriage, is legal in virtually all countries, with the exception of the Vatican and the Philippines. Unbearableness as a reason for divorce is mentioned only in art. 98(1) FC, in the event of a divorce on the proposal of one of the spouses. This also follows from the case law, where the courts have confirmed that divorce is appropriate if marriage is unbearable for one of the spouses (ECLI:SI:VSMB:2006:III.CP.1924.2006). It does not matter which of the spouses is responsible for making the marriage unbearable. It is a sufficient ground for a divorce when a marriage becomes unbearable due to emotional alienation for one of the spouses (ECLI:SI:VSLJ:2010:IV.CP.4446.2009). According to the court, the legal standard of "unbearableness of marriage" is also met in situations where the plaintiff no longer feels any emotional attachment, respect and understanding regarding the defendant and if they lived apart for at least seven months (ECLI:SI:VSLJ:2013:IV.CP.2973.2013). According to the court, however, the notion of unbearableness of marriage must be interpreted from the perspective of the freedom and dignity of the individual so that no one can be forced to stay in marriage against his/her will. The mere fact that one of the spouses no longer wants to insist on the marriage (the will must be serious and genuine) means that the marriage is unbearable for him/her (ECLI:SI:VSLJ:2011:IV.CP.2756.2011).

\section{Uncontested divorce before a notary in the light of new Slovenian FC}

The notary is, in accordance with art. 137(2) of the Constitution of the Republic of Slovenia (Ustava Republike Slovenije - CRS), a public service regulated by 1 the Notary Act (art. 1 NA). In Slovenia, the Latin type of notary system has been enacted, whereby notarial acts have the effect of public documents (Rijavec, 2002). The essence of the Latin type of notary also lies 
New family code and the dejudicialization of divorce in Slovenia

in the autonomy and independence of the performance on the part of the notary service, which is performed by professionals with public authority delegated by the state. The notary shall limit his or her work solely to providing notarial services, to the exclusion of any other occupation, and the basic activities of this type of notary are both to ensure legal certainty and to avoid conflicts (Oruč, 2011, p. 135). Although the notary exercises public authority, he/she is responsible for the breach of official duty related to the exercise of this public authority (Podgoršek, 2010, p. 49).

One of the key reforms brought about by the new FC is the possibility of a divorce by a notary (art. 97 FC). The life dynamic of such a proceeding is fast, and under art. $97 \mathrm{FC}$ spouses who do not have joint children, over whom they would have shared parental care, are enabled to divorce quickly. Spouses in Slovenia now have three options for divorce:

a) a contested divorce by a court on the proposal of one of the spouses (art. $98 \mathrm{FC}$ and 81(3) NCCPA-1); or

b) an uncontested divorce by a court on the joint proposal of both spouses (art. 96 FC and 81(4) NCCPA-1); or

c) an uncontested divorce by a notary (art. 97 FC).

Although art. 97 FC refers solely to divorce, it also applies to the termination of a civil union. Based on the art. 4(10) CUA ("The termination of a civil union, as set out in the law governing the termination of marriage, shall apply mutatis mutandis to the termination of a civil union."), partners from a civil union may also 'divorce' before a notary. In Slovenia, the institution of 'marriage' is intended only for opposite-sex partners, while the 'civil union' is intended for same-sex partners (comp. art. 3(1) FC and 2(1) CUA). An attempt to legislate on equal treatment between opposite-sex partners and same-sex partners in the field of marriage has failed. In 2012 and 2015, two referendums were held in Slovenia, the content of which was related (among others) to the issue of the possibility of marriage between same-sex partners. Voters rejected such regulation in both referendums (Kraljić, 2017, p. 63).

If the spouses wish to divorce by mutual agreement, they must agree on:

a) the division of joint property;

b) who remains or becomes a tenant of the apartment in which they live;

c) the maintenance of a spouse who has no means of subsistence and who is not employed without his fault (art. 97(1) FC).

The FC conditioned an uncontested divorce by a notary upon the spouses' agreement on the three matters listed above. Comparative law, in particular in Romania, also implies the assumption that the spouses shall also agree on the 
surname that the spouses will have after the divorce. They may retain the surname they had at the time of marriage or may take back the surname they had before the marriage (art. 376(5) NCCR; Papa \& Ţăpuş, 2011, p. 345).

An uncontested divorce before a notary, however, is only possible under the FC if the spouses do not have a joint child (ren) over whom they have parental care. ${ }^{2}$ The legislature thus retained the primacy of jurisdiction in matrimonial matters solely for the courts where a child (ren) is involved. Namely, the court is obliged to examine of its own motion whether the care, upbringing, child maintenance and contact regulation after the divorce of the parents is in accordance with the best interest of the child (comp. art. 96(2) and 98(3) FC). Some countries which allow divorce before a notary, also allow it in the case of joint minor children over whom the spouses have parental care (e.g. Latvia (European Judicial Network, 2019a), Colombia (UNCHR, 2020) or Romania (Papa \& Ţăpuş, 2011, p. 345)).

According to legal regulation, the substantive jurisdiction for divorce is divided between the non-contentious court and the notary who will only draw up the notarial deed on divorce agreement of the spouses (art. 97(1) FC). However, there is a difference in territorial jurisdiction. In the case of a divorce on the basis of a proposal of one of the spouses, the jurisdiction could be based on: a) general territorial jurisdiction, which is given to the court on territory, where the person against whom the proposal is filed, is resident (art. 11(1) NCCPA-1); b)or on special territorial jurisdiction, which is given to the court on which territory the spouses had their last common residence. The latter is also given in the case of an uncontested divorce under the art. 96 FC. Spouses who wish to divorce by mutual agreement before a notary can choose arbitrarily any notary in Slovenia, since the territorial jurisdiction of notaries does not exist. By the art. 12(1) NA the notary may provide professional notarial services for the entire territory of Slovenia. This is not possible in the case of a divorce by a non-contentious court. Here, Slovenian law also stands in contrast to Romanian law, since in Romania the notary's divorce is determined by the territorial jurisdiction of the notary at the place where the marriage was concluded or at the place of the marital couple's last family residence (Crăciun, 2014). Spain also adheres to the territorial jurisdiction, as the spouses may be granted divorce by a notary who shall be located in the municipality in which the spouses had their last marital residence or where one of the spouses has his/her current residence (Marbella Solicitors, 2018).

In accordance with art. 22 NA, a notary may not draw up documents from which that notary would directly derive rights or obligations, for that notary's spouse or a person with whom that notary lives in an extra-marital union; for persons with whom that notary is a relative in a lineal line to any degree, or a

${ }^{2}$ In Bolivia the divorce in front of a notary is possible only for cases in which the spouses haven't minor children or property in common (Navaro, n.d, p. 4). 
relative in a sideline or in-law to the second degree; or to persons to whom that notary is an adopter or adoptee, foster parent or guardian, or legal representative or proxy. If, however, the notary drafts a notarial deed, it will not have the effects of a public document.

Even in cases where the spouses inform the notary that, for example, they already have been given legal advice by the attorney about the possibilities and consequences of divorce before a notary, the notary still must, in accordance with the notary's explanatory duty, explain the consequences of divorce (Podgoršek, 2017, p. 58). A distinction must be made, however, between a general and a specific explanatory duty. The general explanatory duty binds a notary in all cases and is legally required. The special explanatory duty dictates that in a particular case the notary must advise the spousesaboutnot only particular risks that may arise upon divorce but also from legal consequences resulting from divorce (Rijavec, 2017, p. 58; Kraljić, 2019, p. 283).

According to the NA, the notary must perform all notarial tasks honestly and conscientiously (Tičar Bešter, 2016, p. 317). Special attention is needed when concluding a contract for the regulation of matrimonial property relations, since it is a new contract, and accordingly can lead to misuse and thus endanger or even violate the principle of equality of spouses (comp. art. 53(1)(1) CRS and $21 \mathrm{FC}$ ). Therefore, since a notary must also take into account the principle of the equality of spouses (as parties to the contract) and thus prevent the occurrence of any possible social perils to the other spouse or children, in situations where the notary concludes the proposed contract would be in violation of the principle of spousal equality the notary should refuse to conclude such an agreement (Končina-Peternel, 2018, p. 14). A notary shall exercise the due diligence of a good expert, otherwise any slight omission and negligence may be the basis for the notary's fault-based liability (ECLI:SI:VSRS:2009:II.IPS.223.2008).

In order to avoid this potential professional notarial liability, a notary must, before the divorce, provide the spouses with impartial counselling or independent instruction on the legal consequences and potential risks inherent in the divorce proceedings (Erjavec, 2019, p. 312). A notary, therefore, before compiling a notarial deed on an uncontested divorce, must clearly describe the content, legal consequences of the intended consensual divorce, and explicitly warn the spouses of known and common risks associated with entering into such a legal transaction or declaration of will. The statutory wording "in an understandable way" indicates the notary's duty to personalize individual counselling to parties (spouses). A notary should take the parties' individual abilities (e.g. type and amount of property, desires, and ability to understand, age...) into account. Merely following the established patterns and legal provisions is not sufficient. While the failure by a notary to discharge his/her notarial duty does not itself invalidate the contract, that failure may result in 
the notary suffering liability (Medicus \& Petersen, 2011; Mitrović, 2019, pp. 59-60; art. 6(2) NA). A notary shall discourage parties from utilizing unclear, incomprehensible or ambiguous statements and explicitly warn them of the possible legal consequences of such statements (e.g. spouses agree on a 4:1 division of assets, which deviates from established practice). Spouses are free to regulate their relations, but not in ways that are contrary to the CRS, mandatory regulations or moral principles. Therefore, the notary has a duty to determine the spouses' actual situation on a case-by-case basis taking all relevant factors into consideration (Rijavec, 2017, p. 57). If the spouses insist on their declarations, the notary must enter them in the notarial deed, including the warnings given by the notary to the parties regarding them (art. 42 NA). This is the so-called notary's recording duty. This record, which is an integral part of the mandate relationship between a notary and the parties to the legal transaction, relieves the notary of liability for damage that may occur to the party as a result of any provision in the legal transaction, which the notary advised the parties against including in the legal transaction (ECLI:SI:VSLJ:2014:II.CP.1263.2013). A notary must always remain impartial and treat both spouses equally. However, a notary will deviate from this principle if he/she observes or determines that this is necessary in order to ensure the equal position of parties (Rijavec, 2010, p. 30; Rijavec, 2017, p. 56; Mitrović, 2019, p. 60; Kraljić, 2019, p. 284).

However, in a situation where a notary ascertains that certain divorce prerequisites are not met, the notary must refuse to draw up a notarial deed. Notaries do not have decision-making powers in matrimonial matters, but can only draw up a notarial deed regarding spouses' divorce agreement. Furthermore, a notary must refuse (comp. art. 24.a(2) NA) to conclude a divorce agreement upon becoming informed that one of the spouses does not qualify for divorce, namely that the divorce is contrary to the free will of one of the spouses; or, if one of spouses is absent at the time of filing a proposal for a divorce by a notary; or, if one spouse withdraws from the agreement or does not want to sign it (Kraljić, 2019, p. 285).

Building on art. 36 NA, the notarial deed relating to the consensual divorce, in cases where itconsists of several pages, must be signed on each page by the notary and each spouse. If one of the spouses is illiterate or dysgraphic (i.e. is either unable to read or to write, or in some cases both), two witnesses or another notary must participate in the composition of the notarial deed. The illiterate and/or dysgraphic spouse must place his/her hand sign on the document and this must be confirmed by two witnesses or the second notary with their signature (art. 37 NA). However, in Romania, if one or both spouses are deaf, mute, deaf-mute, or if they do not understand the Romanian language, the presence of an interpreter, who will sign the divorce application, is required (Papa \&\& Ţăpuş, 2011, p. 345). 
The notary's further actions must also be discontinued if he/she learns that one of the spouses has filed a proposal for divorce at the court (the same in Bolivia), or if one of the spouses passed away, as the latter will result in the termination of the marriage due to death. The notary must also discontinue working cases where the spouses are unable to agree on the division of their joint property, or who will remain or become the tenant of the apartment where they lived, or about the maintenance of the dependent spouse. The reason this is the case is simple. Notaries legally do not have the competences for resolving these impasses. In any such case, the notary under the principle of diligence should refer the spouse to a court.

The Slovenian FC does not provide for the inclusion of an attorney(s) in uncontested divorce proceedings before a notary (the same in Colombia (UNCHR, 2020)), whereas from a comparative law standpoint their presence is obligatory in Spain, France and Greece. In Greece, the spouses may divorce themselves before a notary even if they have minor children over whom they have parental care. However, since protecting the best interests of the children is of paramount concern, any such agreement has limited temporal validity. It is valid for only two years (art. 1441(2) AK). The spouses are thus under legal obligation to renegotiate again in two years and to adapt the new agreement to the new circumstances.

The Slovenian FC has not foreseen the direct enforceability for the notarial deed of the spouses' divorce agreement. However, the direct enforceability of a notarial divorce agreement is provided in France, where the agreement constitutes an enforceable title. The Slovenian legislature wanted to leave the decision regarding whether the spouses' mutual commitments should be enforceable to the spouses themselves. This spousal freedom also enables them to exercise autonomy in this legal field (Erjavec, 2019, p. 310).

In Greece, divorce can result only by the entry of a notarial deed on divorce in the civil registry at the Registry Office at which the marriage was concluded (Art. 1441(5) AK; Economou \& Associates, 2018). According to the Slovenian FC, on the other hand, the marriage will be dissolved from the date of signature of the notarial deed, which is the legal basis for the registration of the divorce in the registry (art. 97(2) FC). According to the Slovenian legislation, a notarial deed on a divorce achieves a constitutive effect with the signature of both spouses. The notary does not declare the spouses as being divorced. The notary must send the notarial deed to the administrative unit, which will enter the divorce into the registry. Registration must take place within eight days from the signature of the notarial deed (art. 97(3) FC).

Regarding the Slovenian FC, the spouses are able to divorce by a notary, based on a consensual agreement, only if they do not have joint children. Despite this, it should not be overlooked, that the notary may become informed in the divorce proceedings of various personal data as well as of 
circumstances that interfere in the deepest family relationships (e.g. between the spouses or other family members) or that relate to property relations affecting the sphere of entrepreneurship (e.g. patents, manufacturing process, balance sheets...). For this reason, the notary is obliged to protection of professional secrecy. In accordance with art. $25 \mathrm{NA}$, he shall keep confidential the information on persons, facts or legal relationships in respect of which a notarial deed is drawn up, insofar as nothing else arises from the will of the parties or the content of the legal transaction. Disclosure of professional secrecy is also a criminal offence of "Unlawful Disclosure of Professional Secrecy" (art. 142 of Criminal Code (Kazenski zakonik)):"Whoever unlawfully discloses a secret which he has become party to in his position shall be punished by a fine or imprisonment for not more than one year. However, where the disclosure of a secret is made for the general good or for some other person's benefit, and where the good or benefit therein is greater than that of withholding the secret, he shall not be punished. The prosecution shall be initiated upon a private action."

\section{Final thoughts}

The reform of family law was necessary. The development itself in this field has required a radical approach to this topic, as it is a legal field which, by its content, encroaches in the deepest sphere of human relations, especially when children are involved. One of the key novelties instituted by the FC is the enactment of a third type of divorce - an uncontested divorce before a notary. This type of divorce has already been regulated by several European countries. Slovenia thus joins the growing list of countries that afford spouses a meaningful alternative to the traditional court proceedings. To avail themselves of this new option, it is sufficient for the spouses to agree on the prescribed assumptions and for the notary to transfer or record their agreement in the form of a notarial deed, which is not directly enforceable. The marriage will be dissolved from the date of signing of the notarial deed. The notarial marriage dissolution option therefore aims to simplify and facilitate the divorce process, which also means the possibility of a dignified conclusion of a partnership between two persons who no longer wish to continue as spouses, as husband and wife, or as partners of the civil union. Divorce before a notary has numerous advantages, both to private citizens and to the public at large. With respect to the actual parties to the divorce, the notarial option is much quicker, much cheaper, less emotional, less confrontational and less stressful than is the case in the traditional judicial divorce proceeding. The public advantage is that this extrajudicial method of divorce frees the courts to perform other public business, presumably with less delay since traditionally so much court time has been devoted to family law matters. Despite all of the advantages of notarial divorces, it must be 
observed that couples seeking a divorce should not have their access to a court restricted. According to unofficial data, in the first year of FC, about 500 couples were divorced using the new notarial method, which would roughly represent about a quarter of all divorces. Couples utilizing this method also expressed their satisfaction with the new type of divorce, as it significantly streamlined the process, contributed to the relief of the courts, allowed for the dignified termination of the marriage, and the personal satisfaction of the parties. Our conclusion is, that the legislative intent in introducing this new alternative to the traditional judicial divorce was certainly achieved in the first year of FC application.

\section{Bibliography}

Alvaro Lucini, M. (n.d). Notarial Divorce in Spain. Retrieved from: https://mokk.hu/kollokvium/eloadasok/2017/Alvaro\%20Lucini\%20Mateo _A\%20h\%C3\%A1zass\%C3\%A1g\%20felbont\%C3\%A1s\%C3\%A1ra\%20 vonatkoz\%C3\%B3\%20\%C3\%BAj\%20szab\%C3\%A1lyoz\%C3\%A1s\%20 Spanyolorsz\%C3\%A1gban.pptx

Androulidakis-Dimitriadis, I. \& Poulou, E. (2019). Family and Succession Law in Greece. Alphen aan den Rijn: Kluwer Law International.

Charakopoulou, D. (2019). Divorce. Greek Law Digest - The official guide to Greek law. Retrieved from: http://www.greeklawdigest.gr/topics/aspectsof-greek-civil-law/item/216-divorce.

Crăciun, N. (2014). The divorce by the public notary - proceedings. Bulletin of the Transilvania University of Braşov Series VII: Social Sciences • Law, Vol. 7(56) No. 2, 89-196.

Crespo, J. \& Marbella, B. (2016, August 26). The possibility of a divorce by mutual agreement before the notary. BGI Law Magazine. Retrieved from: http://www.bgimagazine.com/legal-news-and-articles/the-possibility-of-adivorce-by-mutual-agreement-before-the-notary/

de Oliveira, G. \& Vítor, P. T. (2019). Family and Succession Law in Portugal. Alphen aan den Rijn: Kluwer Law International.

de Oliveira, G. (2002). Grounds for Divorce and Maintenance Between Former Spouses - Portugal. Retrieved from: http://ceflonline.net/wpcontent/uploads/Portugal-Divorce.pdf .

Economou, G. C. \& Associates (2018). Divorce By Mutual Consent With A Notarial Act - How Long Does It Take To Get Divorced In Greece Nowadays?. Retrieved from: http://www.greeklawdigest.gr/topics/aspects-of-greek-civil-law/item/289divorce-by-mutual-consent-with-a-notarial-act-how-long-does-it-take-toget-divorced-in-greece-nowadays 
Erjavec, N. (2019). 97. Člen [Article 97]. IN: Novak, B. (ed.) Komentar Družinskega zakonika [Family Code Commentary](pp. 307-318). Ljubljana: Uradni list Republike Slovenije.

Eskenazi, D. et al. (2017). The New Divorce by Mutual Consent in France: Recognition and Risks of Post-Divorce Litigation in Common-Law Countries: The Examples of England and the United States. Retrieved from: http://www.familylawweek.co.uk/site.aspx?i=ed177705.

European Judicial Network (2015). Romania. Retrieved from: https://ejustice.europa.eu/content_divorce-45-ro-en.do?member=1.

European Judicial Network (2019a). Latvia. Retrieved from: https://ejustice.europa.eu/content_divorce-45-lv-maximizeMS_EJNen.do?member $=1$.

European Judicial Network (2019b). Portugal. Retrieved from: https://ejustice.europa.eu/content_divorce-45-pt-en.do?member $=1$.

European Judicial Network (2020). Estonia. Retrieved from: https://ejustice.europa.eu/content_divorce-45-lv-maximizeMS_EJNen.do?member $=1$.

Eurostat (2018, April 16). Are more babies born inside or outside marriage? Retrieved from: https://ec.europa.eu/eurostat/web/products-eurostatnews/-/DDN-20180416-1.

Ferrand. F. (2017). Stand des Scheidungsrecht in Frankreich[State of divorce law in France]. In: Dutta, A. (ed.). Scheidung ohne Gericht?: neue Entwicklungen im europäischen Scheidungsrecht [Divorce without the court?: new developments in European divorce law] (pp. 145-184). Bielefeld: Verlag Ernst und Werner Gieseking.

Ferrer Riba, J. (2017). Stand des Scheidungsrecht in Spanien[State of divorce law in Spain]. In: Dutta, A. (ed.). Scheidung ohne Gericht?: neue Entwicklungen im europäischen Scheidungsrecht [Divorce without the court?: new developments in European divorce law] (pp. 119-143). Bielefeld: Verlag Ernst und Werner Gieseking.

Floare, M. (2018). Romania. In: Szeibert, O. (2018). Developments in Family Law - year by Year I (2018) (pp. 149-168).Budapest: Eotvos University Press.

Gromova, E. \& Ivanc, T. (2020). Regulatory sandboxes (experimental legal regimes) for digital innovations in Brics. Brics Law Journal, Vol. VII, no. 2, pp. 10-36.

Kabátek, J. (2019). Divorced in a Flash: The Effect of the Administrative Divorce Option on Marital Stability in the Netherlands, IZA Discussion Papers, No. 12150, Institute of Labor Economics (IZA), Bonn. Retrieved from: https://www.econstor.eu/bitstream/10419/196648/1/dp12150.pdf.

Končina-Peternel, M. (2018). Pristojnost notarjev po Družinskem zakoniku[Jurisdiction of notaries under the Family Code]. Notarski vestnik[Notarial journal], October 2018, 9-21.

Kraljić, S. \& Rijavec, V. (2018). New family code of Slovenia (2017): procedural aspect. Redes. 6(2), 219-233. Retrieved from: 
https://revistas.unilasalle.edu.br/index.php/redes/article/view/4891, DOI:10.18316/redes.v6i2.4891.

Kraljić, S. (2017). Same-sex Partnerships in Eastern Europe: Marriage, Registration or No Regulation? IN: Boele-Woelki, K. \& Fuchs, A. (eds.). Same-sex Relationships and Beyond - Gender Matters in the EU (pp. 5575), (European family law series, 42). Fully revised 3rd ed. Cambridge: Intersentia.

Kraljić, S. (2019). Družinski zakonik s komentarjem[Family Code with commentary]. Maribor: Poslovna zalozba-MB.

Marbella Solicitors (2018). Divorce in Spain before Notary. Retrieved from: http://www.marbellasolicitors.com/divorce-in-spain-before-notary/.

Medicus, D. \& Petersen, J. (2011). Bürgelisches Recht - eine nach Ansprungsgrundlagen geordnete Darstellung zur Examvorbereitungen[Civil law - an presentation for the preparation forthe exam]. München: Verlag Franz Vahlen.

Mitrović, T. (2019). Sporazumni razvod braka $i$ notarijat[Uncontested divorce and notary]. Pravo - teorija i praksa, 7-9, 56-66.

Navaro, F. M. (n.d.). Families' laws in Latin America. Retrieved from: https://www.un.org/esa/socdev/family/docs/egm15/Navarropaper.pdf

Notaires de France (n.d.). Getting divorce in France: Different divorce procedures. Retrieved from: https://www.notaires.fr/en/couplefamily/differents-types-divorce .

OECD (2019). SF3.1: Marriage and divorce rates. Retrieved from: http://www.oecd.org/social/family/SF_3_1_Marriage_and_divorce_rates. pdf.

Oruč, E. (2011). Savremene tendencije u razvoju institucije notara. Anali Pravnog fakulteta Univerziteta u Zenici, 5, 133-151.

Papa, AD. \& Ţăpuş, I. (2011). Notary Procedure and Judicial Procedure for the Divorce with Spouses's Agreement. Challenges of the Knowledge Society. Private Law. Retrieved from: http://journaldatabase.info/download/pdf/notary_procedure_judicial_proc edure.

Pellot-Gonzalez (2018). Matrimonies and Divorces before a Puerto Rico Notary. Retrieved from: https://pellotgonzalez.com/index.php/2017/02/17/word-prueba/.

Perez de Vargas (2020). Express divorce in Spain for Foreigners. Retrieved from: https://perezdevargas.co.uk/blog/the-importance-of-granting-awill/.

Podgoršek, B. (2010). Notarjeva poklicna skrbnost, pojasnilna dolžnost in odgovornost[Notary's professional diligence, explanatory duty and responsibility]. Notarski vestnik[Notarial journal], June, 49-55.

Podgoršek, B. (2017). Pogodba o ureditvi premoženjskopravnih razmerij med zakoncema[Marital agreement]. Notarski vestnik[Notarial journal], October, 21-32. 
Ribot, J. (2018). Spain. In: Szeibert, O. Developments in Family Law - year by Year I (2018) (pp. 183-204).Budapest: Eotvos University Press.

Rijavec, V. (2002). Notariat[Notary]. IN: Šturm, L. (ed.) Komentar Ustave Republike Slovenije[Commentary of the Constitution of the Republic of Slovenia]. Retrieved from: https://e-kurs.si/komentar/notariat/

Rijavec, V. (2010). Z zakonom priznano posebno zaupanje[Special trust recognized by the law]. Notarski vestnik [Notarial journal],June, 2010, 29-31.

Rijavec, V. (2017). Notariat quo vadis? [Notary quo vadis?]. Notarski vestnik[Notarial journal], October, 55-60.

SURS (2018). Vsaka peta dvostarševska družina je zunajzakonska skupnost (18. oktober - končni podatki)[Every fifth two-parent family is extramarital community - 18 October - final data]. Retrieved from: https://www.stat.si/StatWebPDF/PrikaziPDF.aspx $\mathrm{id}=7725 \&$ lang=sl

SURS (n.d.). Osnovni podatki in kazalniki o razvezah zakonskih zvez, Slovenija, letno [Basic data and indicators on divorces]. Retrieved from: https://pxweb.stat.si/SiStatDb/pxweb/s1/10_Dem_soc/10_Dem_soc_05_ prebivalstvo_36_Razveze_05_05M30_razvezeSL/05M3002S.px/table/tableViewLayout2/

Tičar Bešter, M. (2016). Posebnosti notarskega dela pri reševanju vlog v sodnem registru [Peculiarities of notarial work in resolving applications in the court register]. Pravosodni bilten [Judicial bulletin] 3, 317.

UNCHR (2020). Colombia: Information on divorce, including grounds, procedures, length of process, support payments and child custody (2005 January 2006). Retrieved from: https://www.refworld.org/docid/45f1472011.html

\section{Legislation and legal documents}

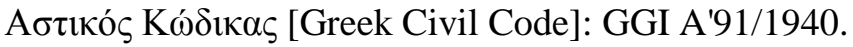

Codigo Civil de Puerto Rico[Puerto Rico Civil Code]: 31 L.P.R.A.

Código de Processo Civil[Civil Procedure Code]: Lei No 13.105/2015, 16 March 2015, and 13.256/2016 Act $\mathrm{N}^{\mathrm{o}}$ 13.105, 16 March 2015, $13.256 / 2016$.

Código do registo civil : Decreto-lei no. 131/95, de 6 de junho (Decree Law No. 131/95).

Decree Law No. 272/2001 on the dejudiziation of divorce by mutual consent, of 13 October 2001.

Družinski zakonik [Family code): Uradni list RS, 15/17, 21/18; 67/19ZMatR-C.

Kazenski zakonik [Criminal code]: Uradni list RS, 50/12- UPB, 6/16 - popr., 54/15, 38/16,27/17, 23/20.

Law 4509/2017: ФEK A' 201/22.12.2017. 
Lege nr. 36 din 12 mai 1995 (republicata) notarilor publici şi a activităţii notariale [Law on Public Notaries and Notary Activity].

Ley 15/2015, de 2 de julio, de la Jurisdicción Voluntaria: BOE» núm. 158, de 3 de julio de 2015 .

Ley Num. 155 de 9 Agosto 2016 (Act No. 155).

Loi ${ }^{\circ}$ 2016-1547 du 18 novembre 2016 de modernisation de la justice du XXIe siècle: JORF ${ }^{\circ} 0269$ du 19 novembre 2016.

Notari tasu seadus[Notary Fees Act]: RT I 1996, 23, 456.

Noul Codul civil al României [New Civil Code of Romania]:Law no. 287/2009 on the Civil Code in no. 202/2010.

Obligacijski zakonik [Obligations Code]: Uradni list RS, 97/07 - UPB, 64/16 - odl. US; 20/18 - OROZ631.

Perekonnaseadus [Family Law Act]: RT I 2009, 60, 395.

Ustava Republike Slovenije [Constitution of the Republic of Slovenia): Uradni list RS, 33/91-I, 42/97 - UZS68, 66/00 - UZ80, 24/03 - UZ3a, 47, 68, 69/04 - UZ14, 69/04 - UZ43, 69/04 - UZ50, 68/06 - UZ121,140,143, 47/13- UZ148, 47/13 - UZ90,97,99, 75/16 - UZ70a.

Zakon o nepravdnem postopku[Non-Contentious Civil Procedure Act]: Uradni list RS, 16/19.

Zakon o notariatu [Notariat Act]: Uradni list RS, 2/07 - UPB; 33/07 - ZSRegB; 45/08; 91/13.

Zakon o partnerski zvezi [Civil Union Act]: Uradni list RS, 33/16.

\section{Cases}

Case C-372/16 - Soha Sahyouni v Raji Mamischu(ECLI:EU:C:2017:686).

Case C-484/15 - Ibrica Zulfikarpašić $v$ Slavenu Gajerju (ECLI:EU:C:2016:654).

ECLI:SI:VSLJ:2010:IV.CP.4446.2009, 12 January 2010.

ECLI:SI:VSLJ:2011:IV.CP.2756.2011, 7 September 2011.

ECLI:SI:VSLJ:2013:IV.CP.2973.2013, 27 November 2011.

ECLI:SI:VSLJ:2014:II.CP.1263.2013, 9 April 2014.

ECLI:SI:VSMB:2006:III.CP.1924.2006, 9 September 2006.

ECLI:SI:VSRS:2009:II.IPS.223.2008, 16 September 2009. 
